\title{
Effect of Supplementation of Partially Defatted Peanut Cake Flour and Dehydrated Spinach Leaves Powder on the Nutritional Quality of Indian Seasonal Sweets
}

\author{
T. Bindhya Dhanesh ${ }^{1 *}$, Anita Kochhar ${ }^{1}$ and M. Javed ${ }^{2}$ \\ ${ }^{1}$ Department of Food and Nutrition, College of Home Science, Punjab Agricultural \\ University, Ludhiana, Punjab, India \\ ${ }^{2}$ Department of Stat, Math and Physics, College of Basic Sciences, Punjab Agricultural \\ University, Ludhiana, Punjab, India \\ *Corresponding author
}

\section{A B S T R A C T}

Keywords

Partially defatted peanut cake flour, Dehydrated spinach leaves powder, Traditional seasonal sweets, High available protein

\section{Article Info}

Accepted: 04 February 2018 Available Online: 10 March 2018

Partially defatted peanut cake flour is an under utilisied, cheap peanut by-product which is packed with high available protein, energy, minerals and vitamins. Indian traditional seasonal sweet products namely Pinni and Panjiri were developed incorporating partially defatted peanut cake flour at $15 \%$ and dehydrated spinach leaves powder at $2 \%$ level so as to increase its nutritional quality. The products were evaluated for its nutritional quality along with its control to assess the increase in nutritional parameters. The nutritional analysis of the products revealed a significant increase in the proximate composition especially protein in the range of $19-20$ per cent, fat $26-27$ per cent, fiber $20-25$ per cent and energy 506-507 Kcal. Mineral composition like iron, calcium and zinc also increased in the fortified products. Higher percent of in vitro protein digestibility and higher amino acid profile was observed in the fortified products compared to the control which were not fortified. Thus the study revealed that the value added products prepared by using partially defatted peanut flour and dehydrated spinach leaves powder can be a promising solution to eradicate malnutrition.

\section{Introduction}

India still ranks the highest in the rate of undernourished children even though it has witnessed significant progress in its battle against child under nutrition over the past decade. National Family Health Survey (NFHS) has very recently reported that the progress in eradicating malnutrition has shown an uneven progress and the situation remains high in many parts of the country (Live mint,
2017). The worst affected states were West Bengal and Maharashtra where every second child is undernourished.

Apart from poverty, the other key reasons for child under nutrition are the status of women, the kind of diet fed to the children and access to good hygienic and sanitation facilities. Out of these diet and poor access to healthy balanced food is the main reason for the increasing occurrence of child under nutrition. 
Reduced dietary diversification has serious effect on the nutrition and health of rural and urban population and deprives rural farmers of opportunity to generate income from their produce, whereas dietary diversification is widely accepted as cost-effective and sustainable way of improving malnutrition (Tontisirin, 2014). Underutilised food resources constitute to the bedrock of the diversity in traditional food systems of developing country communities and tribes. One such underutilized by-product is partially defatted peanut cake flour.

Defatted peanut meal is a by-product left after the oil extraction of peanuts. This meal can be dried and ground into flour which can be used in many recipes to improve nutritional quality. Peanuts are a rich source of protein and have a desirable fatty acid profile and are a rich source of minerals and bioactive compounds (Zhao et al., 2012). Compared to peanuts, defatted peanut flour is of better quality because availability of protein is increased after deoiling. Defatted groundnut flour produced from cake blends easily with any flour and enhances the nutritive value of wheat flour and other flour products (Purohit and Rajyalakshmi, 2011).

In India, significance of peanut flour has started to gain significance because of its high nutritional profile and also in developing cost effective food formulations such as in candies and biscuits (Bassey et al., 2013).

Hence the present study was undertaken to develop two traditional sweet value added products using partially defatted peanut cake flour along with small quantities of dehydrated spinach powder. The products were analysed for their nutritional composition so as to check by how far their nutritional profile can be enhanced and whether these products may be fit to be introduced in various nutritional feeding programmes.

\section{Materials and Methods}

\section{Purchase and processing of ingredients}

Wheat flour, Chick pea flour, Raw peanuts, spinach leaves as well as other ingredients like oil, ghee and powdered sugar were procured from the local market of Ludhiana in a single lot. Peanuts were purchased and checked for any infestation or damage. They were roasted and de-skinned. Oil was extracted by using oil extraction machine.

The residual cake was then collected and further dried in the oven at $65^{\circ} \mathrm{C}$ for half an hour. Dried cake was ground to fine powder. Spinach leaves were procured dried in a tray drier at $60^{\circ} \mathrm{C}$ for 5-6 hours (constant weight was achieved in this time). The dried spinach and fenugreek leaves were ground to fine powder- spinach leaf powder (SLP) and fenugreek leaf powder (FLP) stored in separate airtight containers.

\section{Preparation of Pinni and Panjiri}

Two traditional Indian sweet products namely Pinni and Panjiri were developed. The basic ingredient used for the products was cerealpulse mix flour. Pulse flour was taken in onethird amount of cereal flour. This mix was replaced for the main ingredient listed in the standard procedure. Wheat flour was used as a cereal source and chickpea flour was used as a pulse source. The standard procedures used for product development were as follows:

Pinni - Wheat flour $(100 \mathrm{~g})$ is roasted in $50 \mathrm{~g}$ ghee and mixed well with powdered sugar (Bansal, 2013).

Panjiri - Wheat flour $(100 \mathrm{~g})$ is roasted in $60 \mathrm{~g}$ of ghee. It is then removed from flame and mixed well with powdered sugar and rolled into small ball when warm (Nagi and Mann, 2003). 
The value added products were prepared with partially defatted peanut cake flour and dehydrated spinach leaves powder. Control samples for both the products were prepared. The products Pinni and Panjiri were incorporated with 15 per cent of peanut cake flour and 2 per cent spinach leaves powder as per several reference studies on acceptability of partially defatted peanut cake flour. Proportion of all the ingredients used for the products are given in Table 1.

Sensory evaluation of the value added products

The value added sweet products were prepared in the Food Laboratory of Department of Food and Nutrition, Punjab Agricultural University, Ludhiana. Each of the two developed readyto-eat supplementary foods for malnourished children was prepared fresh, coded randomly and compared treatment wise by ten trained panelists including faculty of department of Food and Nutrition of Punjab Agricultural University in the age range of 45 to 55 years using 9 point hedonic scale for different parameters such as appearance, colour, texture, aroma, taste and overall acceptability (Larmond, 1970).

The sensory evaluation was conducted between 11 am to $12 \mathrm{pm}$ which is regarded to be appropriate to get best results. Water and plain crackers were provided to the panelist so as to clear their taste buds after each sample.

Nutritional analysis of the value added products

The developed value added sweet products were then subjected to nutritional analysis for proximate, mineral, vitamin and amino acid content using standard procedures. In vitro protein digestibility was also analysed. Both the control (without peanut flour and spinach leaves powder) and the acceptable product were analysed so to compare the increase in the nutritional profile.

Proximate Composition - Proximate composites like Moisture, Crude Protein, Crude Fat, Crude Fiber, Crude Ash, Carbohydrates and Energy were analysed using standard procedures suggested by AOAC (2000).

Total minerals - Elements namely iron, calcium, zinc and phosphorus were estimated using atomic absorption spectrophotometer (AAS, Varian model) after wet digestion (Piper, 1950).

Vitamins - Vitamins like Ascorbic Acid was analysed using standard procedures given in AOAC (2000) and Beta carotene was estimated by column chromatography method as explained by Rangana (1995)

In vitro protein digestibility - It was carried out by the by macro kjeldahl method (Akeson and Stachman 1964).

Amino acids - Amino acids like Tryptophan (Concon, 1975), Methionine (Horn et al., 1946) and lysine (Carpenter 1960) as modified by Booth (1971) were analysed.

Anti-nutritional composition - Phytin phosphorous was analysed using the procedure suggested by Haug and Lantzsch (1983), Total phenols (AOAC 2000), Tannin (Ranganna 2001) and Aflatoxins from the samples were extracted by using the method of Barabalok et al., (1974) and further detected using the Pressure Mini Column methods (PCM) Sashidhar et al., (1989).

\section{Statistical analysis}

The nutritional analysis scores were analysed using paired t-test. The values are expressed as Mean \pm SE (Standard error). 


\section{Results and Discussion}

Sensory evaluation of the value added products using defatted peanut cake flour and dehydrated spinach powder

The developed value added pinni scored an overall acceptability of 7.62 and control received the highest score of 8 . Pinni prepared with different combination of cereal and pulse flours were studied for sensory and nutritional parameters by Talawar and Brar (2015). The authors found that Control (Wheat flour) pinni scored the highest scores for sensory attributes followed by pinni prepared using wheat flour and suji followed by those prepared using wheat flour and chickpea flour.

The test sample of panjiri with 15 per cent peanut cake flour and 2 per cent dehyadrated spinach leaves powder scored 7.54 compared to that of control which an overall acceptability score of 8 . Similar study by Bansal (2013) also revealed that increasing incorporation of peanut flour till 50 per cent enhanced the sensory parameters of panjiri and was highly acceptable by the panelists. Salve et al., (2011) reported that panjiri fortified with roasted wheat, soybean and chickpea flour with 10 per cent skimmed milk powder was not only nutritionally superior but also was highly acceptable by the panelist. Panjiri and sweet porridge prepared with 20 per cent wheat, 15 per cent bajra and 65 per cent moong flour scored the highest scores for all the sensory parameters compared to the products prepared with only wheat flour (Srivastava et al., 2015).

\section{Nutritional evaluation of the value added products}

\section{Proximate composition}

The proximate composition of both the control and acceptable products were analysed and is presented in Table 2. Moisture content increased significantly $(p<0.05)$ on incorporation of peanut flour and dehydrated spinach leaves powder in both the products. A significant increase $(p<0.05)$ in the protein as well as fat content of both the products was observed. Highest fiber content was observed in pinni followed by panjiri. The difference in the total ash content of pinni was found to be insignificant.

Similar studies conducted by Sadana and her coworkers (2008) and Bansal (2013) reported that the proximate composition of panjiri increased significantly. Panjiri developed by using cereal and legume flour like wheat flour, soybean flour and chick pea flour in different combination and fortified with $10 \%$ skimmed milk powder contained higher amount of protein and other nutrients. They contained proteins $(16.2$ to $21.1 \%)$, fat (1.9 to $4.5 \%$ ), fiber (1.28 to $1.78 \%)$, ash $(0.7$ to $1.40 \%)$ and carbohydrates (67.66 to $77.2 \%$ ). The total energy expressed in terms of Kcal per $100 \mathrm{~g}$ of product varied from 350.7 to 395.8 (Salve $e t$ al., 2011).

Fiber content for both value added pinni and panjiri also increased on the incorporation of peanut flour and spinach powder significantly as seen in Table 2. Salve and his coworkers (2011) also observed similar increase in these parameters in panjiri developed using different cereals and pulse flour along with skim milk powder. Kaur and Sharma (2017) also observed an increase in the protein as well as fiber content of laddoos and panjiri developed incorporating pumpkin seeds.

\section{Amino acid profile}

An increase in the amino acid concentration was observed on the addition of partially defatted peanut cake flour and dehydrated spinach leaves powder (SL) as depicted in Table 3. 
Table.1 Composition of various test samples of products with partially defatted peanut cake flour and green leafy vegetable powder

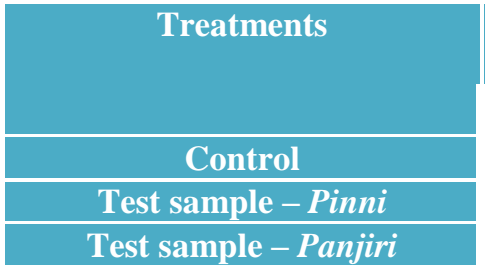

\begin{tabular}{|c|c|c|c|}
\hline Refined wheat flour & Chick pea flour & DPF & SL \\
\hline 75 & 25 & - & - \\
\hline 61.50 & 21.50 & 15 & 2 \\
\hline 61.50 & 21.50 & 15 & 2 \\
\hline
\end{tabular}

Table.2 Proximate composition of developed products (dry weight basis) (g / 100 g)

\begin{tabular}{|l|c|l|l|l|l|c|c|}
\hline Products & Moisture & $\begin{array}{l}\text { Crude } \\
\text { Protein }\end{array}$ & Crude Fiber & Crude Fat & Total Ash & $\begin{array}{l}\text { Carbohydrates } \\
\text { (by differences) }\end{array}$ & $\begin{array}{l}\text { Energy } \\
\text { (Kcal/100g) }\end{array}$ \\
\hline Pinni (control) & $4.31 \pm 0.012$ & $11.02 \pm 0.048$ & $1.41 \pm 0.008$ & $25.11 \pm 0.049$ & $2.54 \pm 0.023$ & $63.01 \pm 0.092$ & $494.64 \pm 0.08$ \\
\hline Test (DPF+SL) & $4.53 \pm 0.006$ & $20.18 \pm 0.026$ & $3.84 \pm 0.012$ & $27.05 \pm 0.020$ & $3.20 \pm 0.225$ & $45.52 \pm 0.206$ & $506.00 \pm 0.61$ \\
\hline t-value & $31.177^{* *}$ & $418.914^{* *}$ & $120.176^{* *}$ & $66.645^{* *}$ & $3.128^{\mathrm{NS}}$ & $145.080^{* *}$ & $16.295^{* *}$ \\
\hline $\begin{array}{l}\text { Panjiri } \\
\text { (control) }\end{array}$ & $4.72 \pm 0.011$ & $11.27 \pm 0.023$ & $1.42 \pm 0.014$ & $24.49 \pm 0.064$ & $2.17 \pm 0.037$ & $62.33 \pm 0.240$ & $500.68 \pm 0.84$ \\
\hline Test (DPF+SL) & $4.91 \pm 0.008$ & $18.97 \pm 0.057$ & $3.86 \pm 0.036$ & $26.96 \pm 0.021$ & $2.89 \pm 0.017$ & $47.21 \pm 0.083$ & $507.69 \pm 0.14$ \\
\hline t-value & $10.522^{* *}$ & $166.133^{* *}$ & $48.306^{* *}$ & $28.649^{* *}$ & $13.073^{* *}$ & $92.493^{* *}$ & $9.939^{* *}$ \\
\hline
\end{tabular}

Values are expressed as Mean \pm SE (Standard Error)

** Significant at $1 \%$ level *Significant at $5 \%$ level

Level of significance $(\mathrm{p}<0.05)$

NS- Not significant

Table.3 Amino acid content of the developed products (mg / $100 \mathrm{~g}$ )

\begin{tabular}{|l|l|l|l|}
\multicolumn{1}{|c|}{ Products } & \multicolumn{1}{|c|}{ Lysine } & \multicolumn{1}{c|}{ Methionine } & \multicolumn{1}{c|}{ Tryptophan } \\
\hline Pinni (control) & $451.850 \pm 0.416$ & $168.243 \pm 0.323$ & $128.473 \pm 0.241$ \\
\hline Acceptable (DPF+SL) & $587.810 \pm 0.837$ & $182.308 \pm 0.337$ & $142.080 \pm 0.150$ \\
\hline t-value & $113.464 * *$ & $21.299 * *$ & $147.778 * *$ \\
\hline Panjiri (control) & $450.170 \pm 0.487$ & $170.940 \pm 0.355$ & $132.150 \pm 0.086$ \\
\hline Acceptable (DPF+SL) & $582.2132 \pm 0.646$ & $185.960 \pm 0.285$ & $147.983 \pm 0.573$ \\
\hline t-value & $389.130 * *$ & $50.092 * *$ & $24.143 * *$ \\
\hline
\end{tabular}

Values are expressed as Mean \pm SE (Standard Error)

Level of significance $(\mathrm{p}<0.05)$

** Significant at $1 \%$ level *Significant at $5 \%$ level

NS- Not significant

Table.4 Mineral and Vitamin content of the developed products (mg / $100 \mathrm{~g}$ )

(" fresh weight basis)

\begin{tabular}{|c|c|c|c|c|c|c|}
\hline Products & Calcium & Iron & Zinc & Phosphorus & Vitamin C\# & Bcarotene \\
\hline Pinni (control) & $44.85 \pm 0.421$ & $3.02 \pm 0.006$ & $0.84 \pm 0.012$ & $191.81 \pm 0.255$ & $0.458 \pm 0.017$ & $23.22 \pm 0.321$ \\
\hline $\begin{array}{l}\text { Acceptable } \\
(\mathrm{DPF}+\mathrm{SL})\end{array}$ & $50.23 \pm 0.011$ & $4.86 \pm 0.008$ & $0.99 \pm 0.011$ & $184.39 \pm 0.572$ & $0.200 \pm 0.010$ & $18.34 \pm 0.293$ \\
\hline t-value & $13.060^{* *}$ & $127.096^{* *}$ & $10.094 * *$ & $15.834 * *$ & $21.356 * *$ & $114.513 * *$ \\
\hline Panjiri (control) & $44.89 \pm 0.018$ & $3.23 \pm 0.056$ & $0.76 \pm 0.006$ & $182.56 \pm 0.722$ & $0.453 \pm 0.003$ & $24.73 \pm 0.097$ \\
\hline $\begin{array}{l}\text { Acceptable } \\
(\mathrm{DPF}+\mathrm{SL})\end{array}$ & $48.68 \pm 0.023$ & $4.89 \pm 0.023$ & $0.93 \pm 0.008$ & $172.27 \pm 0.331$ & $0.247 \pm 0.020$ & $19.44 \pm 0.106$ \\
\hline t-value & $569.00 * *$ & $26.050^{* *}$ & $11.930 * *$ & $26.135^{* *}$ & $11.717 * *$ & $26.062 * *$ \\
\hline \multicolumn{4}{|c|}{ Values are expressed as Mean \pm SE (Standard Error) } & \multicolumn{3}{|c|}{ Level of significance $(\mathrm{p}<0.05)$} \\
\hline
\end{tabular}


Table.5 In vitro protein digestibility (\%) of the developed products

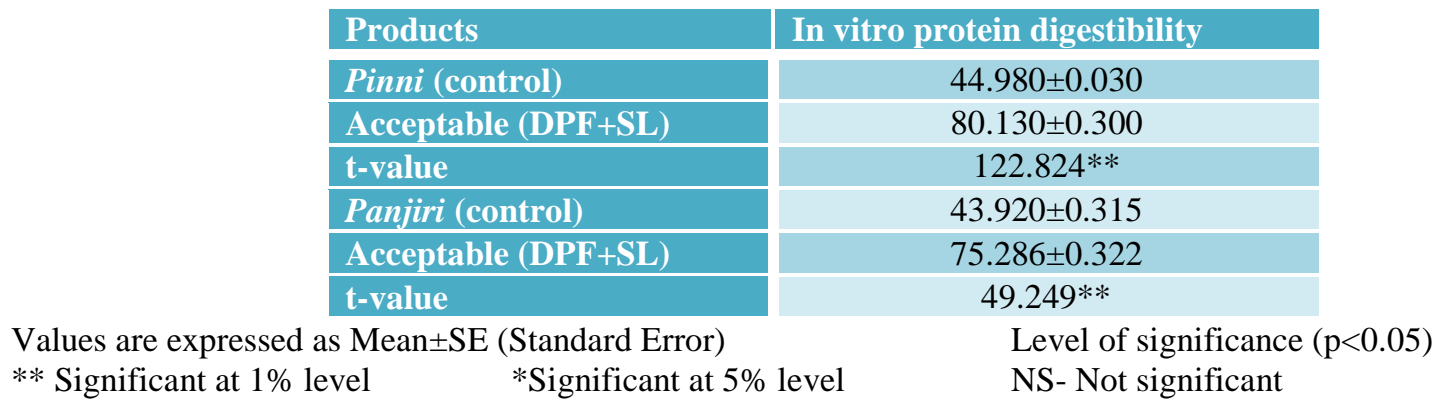

Table.6 Antinutritional composition in the developed products (mg / $100 \mathrm{~g}$ )

\begin{tabular}{l|l|c|c|}
\hline \multicolumn{1}{|c|}{ Products } & Phytin Phosphorus & Total Phenol & Tannin \\
\hline Pinni (control) & $96.030 \pm 0.026$ & $95.910 \pm 0.009$ & $50.986 \pm 0.028$ \\
\hline Acceptable (DPF+ SL) & $93.453 \pm 0.126$ & $96.796 \pm 0.028$ & $49.830 \pm 0.270$ \\
\hline t-value & $39.875 * *$ & $18.057 * *$ & $4.783 *$ \\
\hline Panjiri (control) & $94.783 \pm 0.017$ & $94.286 \pm 0.057$ & $50.890 \pm 0.555$ \\
\hline Acceptable (DPF+SL) & $92.883 \pm 0.024$ & $95.943 \pm 0.043$ & $46.963 \pm 0.218$ \\
\hline t-value & $22.824 * *$ & $58.169 * *$ & $10.973 * *$ \\
\hline $\begin{array}{l}\text { Values are expressed as Mean } \pm \text { SE (Standard Error) } \\
\text { * Significant at 1\% level }\end{array}$ & *Significant at 5\% level & Level of significance $(\mathrm{p}<0.05)$ \\
\hline
\end{tabular}

Statistically significant increase in the lysine, methionine and tryptophan content of both the products were observed on fortification with peanut flour and SL powder.

Omwamba and Mahungu (2014) reported a concentration of 88-90 per cent lysine content in Protein-Rich Ready-to-Eat Extruded Snack from a Composite Blend of Rice, Sorghum and Soybean Flour.

\section{Mineral and vitamin concentration}

As shown in Table 4, the mineral like calcium, iron and zinc increased significantly in the fortified products compared to the control which was not fortified with peanut flour and spinach leaves powder. In a study conducted by Salve et al., (2011) calcium, phosphorus and iron were found to increase on supplementation with $10 \%$ skimmed milk powder to panjiri prepared using cereal legume mix basically wheat flour, soy flour and chick pea flour in different combinations. An increase in the zinc content of laddoos and panjiri was observed by Kaur and Sharma (2017) when the products were supplemented with pumpkin seeds powder. The vitamin content like the vitamin $\mathrm{C}$ and beta carotene content also reduced significantly on fortification of the products which may be due to the reason that peanut flour is deficient in these vitamins and replacement of some amount of wheat flour and chickpea flour reduced the vitamin content. Roasting also contributes to the reduction of vitamin C. Pant (2011) also observed an increase in the betacrotene, vitamin $\mathrm{C}$ and calcium content of laddoos supplemented with spinach and drumstick leaves.

\section{In vitro protein digestibility}

The in vitro protein digestibility of the products increased considerably which was statistically significant $(\mathrm{p}<0.05)$ on the 
fortification of products with peanut flour and dehydrated spinach leaves powder (SL).

Table 5 shows that the highest increase was seen in the case of Pinni from 44.980 to 80.130 per cent and Panjiri from 43.92 to 75.283 per cent which may be due to the highest percentage of peanut flour fortification. Serrem et al., (2011) observed that the in vitro protein digestibility of biscuits increased by 170 per cent in sorghum- soy biscuits compared normal wheat flour biscuits. Baba and his coworkers (2012) In vitro protein digestibity of sprouted sorghum fortified with peanut and cow pea was found to be 96.9 per cent which was significantly higher than sorghum sprouts $(89.9 \%)$.

Anti-nutritional composition of the developed products

With respect to the anti-nutritional composition of the products, the phytin and total phenol increased significantly for both the value added products as shown in Table 6 . This may be due to the spinach powder added to the products. Tannin content reduced significantly for the products. An insignificant increase in the levels of phytates, polyphenols and a significant increase in the oxalate content of laddoos supplemented with spinach and drumstick leaves were observed by Pant (2011). Aflatoxin was not detected in any of the products.

The sweet products namely Pinni and Panjiri prepared using cereal-pulse mix, partially defatted peanut cake flour and dehydrated spinach leaves powder were highly acceptable at 15 per cent level and 2 per cent level respectively. Nutritional analysis of the acceptable products revealed a statistically significant increase in all the proximate components like protein, fat, carbohydrates, fiber and energy. An increase in minerals like calcium, zinc and iron as well as amino acids like lysine, methionine and tryptophan was also observed but there was a decrease in phosphorus content in both the products compared to the control with an increase in in vitro protein digestibility for all products. Thus, supplementation of peanut cake flour and dehydrated spinach leaves powder in traditional snacks as well as sweets can be a promising solution to eradicate malnutrition in our country.

\section{Acknowledgement}

I acknowledge Dr. Anita Kochhar for her immense support in designing the experiment as well as for providing all the necessary needed to conduct the experiment. I also acknowledge Dr. M. Javed for his guidance with the statistical analysis of the experimental data.

\section{References}

Akeson, W. R. and Stahmann, M.A. 1964. A pepsin pancreatin digest index of protein quality evaluation. J Nutr. 83: 257-261.

AOAC. 2000. Official Method of Analysis Association of Official Analytical Chemist, $17^{\text {th }}$ ed. Washington DC.

Baba, G.M., Modu, S., Falmata, A.S., Hajjagana, L. and Ibrahim, Z. 2012. Evaluation of the nutritional value of sprouted sorghum fortified with cowpea and groundnut. Scholarly Journal of Agricultural Science. 2(11): 292-296

Bansal, P. 2013. Development of value added products with peanut flour for nutritional and health benefits. M.Sc. thesis (Food and Nutrition). Punjab Agricultural University, Ludhiana, Punjab. 129p.

Barabalok, R., Colbarn, C. R. and Smith, R. J. 1974. Rapid screening method for examining corn and corn derived 
products for possible aflatoxin contamination. J Assoc Of Anal Chem 57:764-66.

Bassey, F.I., McWatters, K.H., Edem, C.A. and Iwegbur, C.M.A. 2013. Formulation and Nutritional evaluation of weaning food processed from cooking banana and supplementation with cowpea and peanut. Food Sci. Nutr. 1(5): 384-91

Booth, V.H. 1971. Problems in determination of FDNB-available lysine. J Sci Food Agric. 22:658-66.

Carpenter, K.J. 1960. The estimation of available lysine in animal protein foods. Biochem J. 77:604-10.

Concon, J.M. 1975. Rapid and simple method for the determination of tryptophan in cereal grains. Anal Biochem. 67: 206.

Haug, W. and Lantzsch, H.J. 1983. Sensitive method for the rapid determination of phytic acid in cereals and cereals products. J Sci. Food Agri. 3: 14231426.

Horn, M.J., Jones, D.B. and Blum, A.E. 1946. Colorimetric determination of methionine in proteins and foods. J Biol Chem. 166:313-20.

Kaur, M. and Sharma, S. 2017. Development and nutritional evaluation of pumpkin seed (Cucurbita moschata) supplemented products. M.Sc. thesis (Food and Nutrition). Punjab Agricultural University, Ludhiana, Punjab. 150p.

Larmond, E. 1970 Methods of sensory evaluation of food. Can Deptt Agric Pubs. 1970:s1284.

Live mint. 2017. BUDGET 2018- What explains India's highest rate of child malnutrition rates? Live mint- E-paper, June 08, 2017. http://www.livemint. com/Politics/MAbkHJ0jYZ1hu9G0obN $\mathrm{XiK} /$ What-explains-Indias-high-childmalnutrition-rates.html
Nagi, M.K. and Mann, S.K. 2003. Traditional Punjabi Recipes. Center for communication, languages and culture. Punjab Agricultural University. 106p

Omwamba, M. and Mahungu, S.M. 2014. Development of a Protein-Rich Readyto-Eat Extruded Snack from a Composite Blend of Rice, Sorghum and Soybean Flour. Food and Nutr Sci. 5(14): 1309-17

Pant, R. 2011. Development and nutritional evaluation of value added cereal-pulse based products using drumstick leaves (Moringa oleifera). M.Sc. thesis (Food and Nutrition). Punjab Agricultural University, Ludhiana, Punjab. 117p

Piper, C. S. 1950. Soil and plant analysis. Interscience Publication, Inc. New York. Pp: 212

Purohit, C. and Rajyalakshmi, P. 2011. Quality of products containing defatted groundnut cake flour. J. Food Sci. Tech. 48: $26-35$

Rangana, S. 1995. Handbook of analysis and quality control for fruit and vegetable products. Tata Mc Graw Hill Publishing Company limited, New Delhi.

Ranganna, S. 2001. Handbook of Analysis and Quality Control for Fruit and Vegetable Products, Ranganna, S. (Ed.). Tata McGraw-Hill Publications, New Delhi. 719-724

Sadana, B., Bakhetia, P. and Agarwal, R. 2008 Nutritional evaluation of germinated wheat and Soybean based supplementary foods. Indian $\mathbf{J}$ Ecol. 35(1): 87-90.

Salve, R.V., Mehrajfatema, Z.M., Kadam, M.L. and More, S.G. 2011. Formulation, Nutritional Evaluation and Storage Study of Supplementary Food (Panjiri). J Food Process Technol 2:131

Sashidhar, R. B., Bhat, R. V. and Vasanthi, S. 1989. Non-competitive Enzyme Linked Immuno-Sorbent Assay for detection of 
aflatoxin $\mathrm{B}_{1}$. Indian J Exp Biol. 26:98489.

Serrem, Charlotte A., de Kock, Henriëtte L., Taylor and John R.N. 2011. Nutritional quality, sensory quality and consumer acceptability of sorghum and bread wheat biscuits fortified with defatted soy flour. Intl. J. Food Sci. Technol. 46(1): 74-83

Srivastava, S., Neerubala, Singh, S. and Shamin M.Z. 2015. Nutritional composition of weaning food using malted cereal and pulse flour for infants. Intl. J. Pure and Applied Biosci. 3(1): 171-185.

Talawar, G. and Brar, S.K. 2015. Study of Physiochemical, Sensory and Color
Properties of Pinni Variants. Ind J Sci Technol. 8(7): 629-34

Tontisirin, K. 2014. Promotion of underutilized indigenous food resources for food security and nutrition in Asia and the Pacific. Chapter 1. Patrick Durst and Nomindelger Bayasgalanb (Eds) at food and agriculture organization of the united nations- regional office for Asia and the pacific Bangkok, 2014. P 21 out of 191.

Zhao, X., Chen, J. and Du, F. 2012. Potential use of peanut by-products in food processing: a review. J. Food Sci. Technol. 49: 521-29.

\section{How to cite this article:}

Bindhya Dhanesh, T., Anita Kochhar and Javed, M. 2018. Effect of Supplementation of Partially Defatted Peanut Cake Flour and Dehydrated Spinach Leaves Powder on the Nutritional Quality of Indian Seasonal Sweets. Int.J.Curr.Microbiol.App.Sci. 7(03): 384-392. doi: https://doi.org/10.20546/ijcmas.2018.703.044 